Friele, R.D. Een thematische evaluatie van het begrip informed consent. Tijdschrift voor Gezondheidsrecht: 2007, 31(8), 614-619

\begin{tabular}{|l|l|}
\hline $\begin{array}{l}\text { Postprint } \\
\text { Version }\end{array}$ & 1.0 \\
\hline $\begin{array}{l}\text { Journal website } \\
\text { http://www.vakbibliotheek.nl/BSL/content/edition/0165- }\end{array}$ & $\underline{\underline{0874 / \text { edition.asp?custom_product_id=0165-0874\&product_id=\{94BBFC39- }}}$ \\
\hline B4F1-4A76-8F34-90AC325CCECD $\}$ \\
\hline DOI & \\
\hline
\end{tabular}

This is a NIVEL certified Post Print, more info at http://www.nivel.eu

\title{
Een thematische evaluatie van het begrip informed consent
}

\author{
DR. IR. R.D. FRIELE* \\ * Roland Friele is hoofd van één van de onderzoeksafdelingen van het NIVEL.
}

\section{INLEIDING}

Een thematische evaluatie rond het begrip 'informed consent', wat moet men zich daarbij voorstellen. Deze vraag is het uitgangspunt voor mijn bijdrage over het onderwerp 'thematische evaluaties'. Bij informed consent draait het om zelfbeschikking. Informed consent dient als waarborg: zonder de toestemming van de patiënt zullen artsen geen medische handelingen op die patiënt verrichten. Het dient ook als waarborg voor artsen: als er informed consent is, dan mag de arts overgaan tot handelingen die in het normale verkeer tussen mensen niet zijn toegestaan en zelfs zouden kunnen leiden tot strafvervolging. Daarmee is informed consent een centraal draaipunt in de (behandel)relatie tussen patiënten en hun arts. Zonder het informed consent-vereiste zou het voor patiënten een hachelijke zaak zijn een arts te bezoeken of voor artsen een even zo hachelijke zaak om over te gaan tot een medische behandeling. Het informed consent-vereiste is onderdeel van verschillende wetten in de gezondheidszorg, zoals de Wet op de geneeskundige behandelingsovereenkomst (WGBO), de Wet medisch-wetenschappelijk onderzoek bij mensen (WMO) en de Wet op de orgaandonatie (WOD). Ik ben bij de evaluatie van deze drie wetten betrokken geweest en wil graag vanuit die invalshoek een voorzet doen hoe een thematische evaluatie van het begrip informed consent eruit zou kunnen zien. Die voorzet zal sterk door de empirie beïnvloed zijn. Dat betekent niet dat ik denk dat een thematische evaluatie van het begrip informed consent een louter empirisch karakter zou moeten hebben. Het tegendeel is waar. Een thematische evaluatie vraagt om een multidisciplinaire insteek: juridisch en empirisch. Door andere auteurs in dit themanummer is het begrip thematische evaluatie vooral vanuit een juridische invalshoek beschouwd. In deze bijdrage zal ik laten zien dat een empirische invalshoek relevante en vruchtbare vraagstellingen kan generen die zich vervolgens ook lenen voor juridische verdieping.

\section{INFORMED CONSENT IN DE WGBO}

Het informed consent-vereiste is een belangrijk element in de WGBO. Voor een uitvoerige beschrijving zie bijvoorbeeld de evaluatie van de WGBO. ${ }^{1}$

"De algemene regel van de WGBO luidt, dat de arts de patiënt op duidelijke wijze, en desgevraagd schriftelijk, inlicht over het voorgenomen onderzoek en de voorgestelde behandeling en over de ontwikkelingen omtrent het onderzoek, de behandeling en de gezondheidstoestand van de patiënt (art. 7:448 lid 1 Burgerlijk Wetboek). Vervolgens 
bepaalt de wet dat de arts zich bij het toepassen van de informatieplicht laat leiden door hetgeen de patiënt 'redelijkerwijze' dient te weten ten aanzien van:

de aard en het doel van het onderzoek of de behandeling;

de te verwachten gevolgen en risico's daarvan voor de gezondheid van de patiënt; andere methoden van onderzoek of behandeling die in aanmerking komen; de gezondheidssituatie van de patiënt en diens vooruitzichten ter zake.” 2 Vervolgens is toestemming vereist voor de uit te voeren verrichtingen.

Er is vrij veel onderzoek gedaan naar de ervaringen van patiënten met informed consent, ook is er observationeel onderzoek: onderzoek waarbij een videocamera in de spreekkamer is geplaatst en waarbij de feitelijke communicatie tussen arts en patiënt wordt geregistreerd. De resultaten zijn vrij consistent. Ik toon u een greep. Ze laten zien dat, in de ogen van patiënten niet altijd wordt voldaan aan het vereiste van informed consent.

\section{[TABLE 1]}

Volgens vrijwel alle patiënten gaf hun huisarts in het consult, waar navraag over werd gedaan, informatie over de behandeling. Veel minder vaak kwamen behandelalternatieven aan de orde. Bijzonder zijn ook de rapportages over de beslissing. In $60 \%$ van de gevallen zeggen patiënten dat ze samen met de huisarts beslisten. Toch zegt ook ruim driekwart dat uiteindelijk de huisarts besliste. Ook uit onderzoek onder patiënten van verschillende medisch specialismen komt naar voren dat niet in alle gevallen patiënten de indruk hebben dat zij meebeslissen. Voor patiënten van de cardioloog geldt dit voor bijna de helft van de patiënten, voor patiënten van de gynaecoloog voor ongeveer een derde en voor patiënten van de orthopeed voor ongeveer een kwart. Ook uit de analyse van video-opnames bij huisartsenconsulten blijkt dat zaken als het informeren over behandelalternatieven of over bijwerkingen lang niet in alle consulten aan de orde komen, terwijl patiënten ze voor dat consult wel belangrijk vonden. ${ }^{3}$ Ondanks deze observaties zijn patiënten over het algemeen zeer te spreken over deze consulten. Kennelijk is er een vrij groot verschil tussen de WGBOvereisten van het informed consent en de praktijk, zonder dat patiënten hier nu bijzonder veel hinder van hebben. Patiënten vinden over het algemeen dat ze goed worden geïnformeerd. ${ }^{4}$

Kennis van hoe beslissingen worden genomen, ook door patiënten, maakt duidelijk waar dit verschil tussen praktijk en de invulling van het begrip informed consent vandaan komt. Allereerst zijn mensen nu eenmaal beperkt in het vermogen om informatie op te nemen. Er is een grote hoeveelheid literatuur waaruit blijkt dat mensen maar een klein deel van de informatie die zij in een consult krijgen onthouden en dus kunnen gebruiken voor een weloverwogen beslissing (zie o.a. Ley, $1982^{5}$ ). Soms willen mensen besluiten ook terugdraaien. Besluitvorming is mede daardoor eerder een proces dan iets wat op één moment in één consult gebeurt. Het is heel onwaarschijnlijk dat mensen in één consult, waarin ze bijvoorbeeld hoorden dat ze een bepaalde ziekte hebben, alle relevante informatie kunnen opnemen, de implicaties van een keuze kunnen overzien en een verantwoorde keuze kunnen maken. Daarnaast is vertrouwen van groot belang. De patiënt die aan de dokter vraagt: “wat zou u zelf doen?”, stelt een belangrijke informatieve vraag. Het antwoord is relevant, maar de relevantie ervan is gebaseerd op het vertrouwen dat mensen hebben in hun arts, niet op de feitelijkheid van de informatie. Deze elementen spelen een rol in een consult tussen arts en patiënt. Ze verklaren voor een deel het fenomeen dat patiënten in objectieve zin niet volledig worden geïnformeerd: ze krijgen bijvoorbeeld vaak geen informatie over behandelalternatieven en kunnen dus geen keuze maken (er is immers geen keuze), terwijl ze toch van mening zijn goed te zijn geïnformeerd.

Daarnaast nemen mensen besluiten vaak niet alleen, maar met familie of vrienden. Met name chronisch zieken hebben ook nog met veel verschillende hulpverleners te maken. Besluitvorming speelt zich dan in een netwerk af, een netwerk van verschillende hulpverleners, familie en vrienden, en niet in dat ene consult met die ene arts. Ten slotte 
kunnen patiënten ook met instellingen te maken hebben, waarmee ook afspraken worden gemaakt.

Er lijkt zich dus een discrepantie voor te doen tussen de manier waarop het begrip informed consent in de WGBO is vormgegeven en de manier waarop in consulten beslissingen worden genomen. Deze discrepantie lijkt voort te komen uit het verschil tussen de praktijk en het te rationele beeld aangaande besluitvorming van de wetgever en de opvatting van de wetgever dat besluitvorming plaats vindt tussen één arts en één patiënt.

\section{INFORMED CONSENT IN DE WMO}

Ook in de WMO speelt informed consent een cruciale rol.

"De Wet medisch-wetenschappelijk onderzoek met mensen bevat, in vergelijking met de WGBO, toegespitste bepalingen. Deze wet noemt in art. 6 lid 3 de onderwerpen waarover een proefpersoon behoort te worden geïnformeerd alvorens hem wordt gevraagd toestemming voor deelname aan een medisch-wetenschappelijk onderzoek te geven. Art. 6 lid 4 bepaalt daarbij nog eens: 'De inlichtingen worden op zodanige wijze verstrekt dat redelijkerwijs zeker is dat betrokkene deze naar haar inhoud heeft begrepen'. Deze laatste formulering is ook van toepassing op situaties waarin een persoon om deelname wordt gevraagd aan een combinatie van een medisch-wetenschappelijk onderzoek en een bevolkingsonderzoek." 6

Het blijkt dat medisch-ethische commissies (METC's) bij de behandeling van een onderzoeksprotocol relatief vaak aan onderzoekers vragen om aanvullingen of verbeteringen in het informatiemateriaal voor patiënten: ${ }^{7}$ één op de drie protocollen wordt door de METC's teruggestuurd naar de onderzoekers om de patiënteninformatie te verbeteren. Een analyse van patiënteninformatiemateriaal in het kader van de evaluatie van de WMO liet echter zien dat het, door METC's, goedgekeurde materiaal toch nog moeilijk leesbaar is. Een eenvoudige leesbaarheidstest liet zien dat het materiaal het beste aansluit bij het leesniveau van studenten. Vervolgens bleken eisen die je vanuit patiëntenperspectief zou moeten stellen aan goede patiënteninformatie niet goed aan te sluiten bij de formele eisen die worden gesteld aan patiënteninformatie bij WMO-plichtig onderzoek. Uit de praktijk komen ten slotte signalen dat patiënten die worden gevraagd of ze willen meedoen in een onderzoekstrial vaak beslissen op basis van het vertrouwen dat zij in hun arts of in de research-verpleegkundige stellen.

Ook bij de WMO lijkt er dus een discrepantie te zijn tussen de manier waarop het begrip informed consent is vormgegeven in de WMO en wordt vormgegeven door de CCMO en de diverse METC's enerzijds en de manier waarop patiënten idealiter ondersteund zouden moeten worden bij het nemen van besluiten anderzijds.

\section{INFORMED CONSENT IN DE WOD}

De waarborgfunctie van de WOD is van groot belang: zonder deze waarborgfunctie geen orgaandonatie. ${ }^{89} \mathrm{Bij}$ de besluitvorming of iemand donor kan zijn, blijken nabestaanden een cruciale rol te spelen. In de WOD wordt gesteld dat nabestaanden moet worden gevraagd om toestemming als de wil van de overledene niet bekend is. In de praktijk blijken nabestaanden veel vaker een rol te krijgen, niet alleen als er niets bekend is over de wil van de overledene, maar ook als wel bekend is dat de overledene toestemming heeft gegeven. In een aantal gevallen leidt dit ertoe dat, ondanks toestemming van de overledene, toch niet tot donatie wordt overgegaan. Het lijkt er op dat er in de praktijk voor nabestaanden een recht op toestemming is ontstaan, dat er in de WOD niet is. Internationaal vergelijkend onderzoek laat overigens zien dat ook in andere landen nabestaanden een belangrijker rol hebben dan formeel in wetgeving is vastgelegd. ${ }^{10}$

In de Tweede Kamer en door veel bij orgaandonatie betrokken partijen wordt met enige regelmaat gepleit voor een wijziging van het beslissysteem in de WOD: van informed consent naar presumed consent. Dit zou, volgens de pleitbezorgers van deze verandering, 
kunnen leiden tot een toename van het aantal donoren. Internationaal vergelijkend onderzoek tussen een aantal Europese landen, waarbij rekening wordt gehouden met verschillen in het aantal mensen dat overlijdt aan een verkeersongeluk of een CVA (de belangrijkste doodsoorzaken van donoren van nieren) laat evenwel zien dat landen met een systeem van veronderstelde toestemming (presumed consent) niet meer donoren kennen dan landen met een systeem van informed consent. ${ }^{11}$ Nabestaanden lijken vaker geneigd in te stemmen met orgaandonatie bij toestemming op basis van informed consent dan bij toestemming op basis van presumed consent. ${ }^{12}$

Ook bij de WOD lijkt er een discrepantie te zijn tussen de plaats van het informed consent in de wet enerzijds en de praktijk anderzijds. Nu gaat het vooral om de rol van nabestaanden, veelal familie. Zij lijken in de praktijk een belangrijker rol te hebben dan waar de wet in voorziet.

\section{CONCLUSIES}

De invulling van het begrip informed consent lijkt zich in de praktijk te hebben ontwikkeld op zulk een wijze dat er mogelijk discrepanties zijn ontstaan tussen de praktijk en de invulling van het begrip informed consent in verschillende wetten. Voor de WGBO geldt dat besluitvorming in de praktijk meer een proceskarakter heeft en ook eerder in een netwerk van personen plaats vindt, dan in een consult op dat éne moment. De eisen die de WMO aan de patiënteninformatie stelt, waar METC's ook zorgvuldig op toezien, lijken niet goed aan te sluiten bij de manier waarop patiënten feitelijk beslissen over eventuele deelname aan een onderzoek. Ten slotte hebben nabestaanden in de praktijk een belangrijker rol als het gaat om het beslissen over orgaandonatie dan waar de WOD ruimte toe geeft.

In een thematische evaluatie over het begrip informed consent zou de vraag naar eventuele discrepanties tussen wet en praktijk centraal moeten staan. Eventuele discrepanties zouden nader in kaart gebracht moeten worden, de oorzaak nader geanalyseerd en nagegaan zou moeten worden of die analyse gevolgen zou moeten hebben voor de betreffende wetgeving of de implementatie hiervan. De vraag kan worden gesteld of het mogelijk is om de uitwerking van het begrip 'informed consent' in de verschillende stukken wetgeving te doen evolueren zodat het beter aansluit bij hoe mensen keuzes maken en tegelijk rechtszekerheid biedt voor patiënten en artsen. Door in een thematische evaluatie niet in te zoomen op maar één wet, maar het thema informed consent centraal te stellen en de ervaringen met het begrip in het kader van verschillende wetten naast elkaar te zetten, kan een breed inzicht worden gekregen in hoe informed consent werkelijk werkt en hoe en of dit in wetgeving te vatten is. Het moge duidelijk zijn dat het hierbij niet gaat om louter empirisch of juridisch onderzoek, maar vooral om een combinatie van beide.

\section{NOTEN}

J.C.J. Dute, R.D. Friele, J.K.M. Gevers, J.H. Hubben, J. Legemaate, H.D.C. Roscam

1. Abbing, B. Sluijters, G.A.M. Widdershoven \& F.C.B. van Wijmen, De evaluatie van de WGBO, Den Haag: ZON 2000.

2.

J. Legemaate, Patiëntenrechten in wetgeving en rechtspraak, Den Haag: IGZ 2006, p. 31.

A. van den Brink, A.M. van Dulmen, F.G. Schellvis \& J.M. Bensing, Tweede nationale

3. studie naar ziekten en verrichten in de huisartsenpraktijk. Oog voor communicatie, NIVEL 2004, p. 112-115.

4. R.D. Friele, A. Albada \& E.M. Sluijs, Patiënten over hun rechten in de gezondheidszorg, een overzichtsstudie ten behoeve van de SGZ 2006, Utrecht: SGZ 2006, p. 8.

5. P. Ley, 'Satisfaction, compliance and communication', British Journal of Social and Clinical Psychology 1982, p. 241-254.

6. J. Legemaate 2006, p. 34 (zie noot 13). 
J.C.J. Dute, R.D. Friele, H. Nys, V.A.J. op den Brink, R.C.W. van Gils, P.E.D. Eysink \&

7. J.E. Hanssen, Evaluatie Wet medisch-wetenschappelijke onderzoek met mensen, Den Haag: ZonMw 2004.

8. R.D. Friele, G.A. Blok, J.K.M. Gevers, R. Coppen \& M.C. Smit, Derde evaluatie van de Wet op de orgaandonatie, Den Haag: ZonMw 2006.

9. R.D. Friele, J.K.M. Gevers, R. Coppen, A.J.G.M. Janssen, W. Brouwer \& R. Marquet, Tweede evaluatie van de Wet op de orgaandonatie, Den Haag: ZonMw 2004.

10 S. Gevers, A. Janssen \& R.D. Friele, 'Consent systems for post mortem organ donations in Europe', Eur. Jnl. of Health Law 2004, p. 175-186.

11 R. Coppen, R.D. Friele, R.M. Marquet \& J.K.M. Gevers, 'Opting-out systems no

11. guarantee for higher donation rates', Transplant International 2005, p. 1275-1279.

12. R.D. Friele \& J. de Jong, Actieve donorregistratie? Een herhalingsonderzoek naar de mogelijk reacties op een actieve donorregistratie, Utrecht: NIVEL 2007.

\section{TABEL}

Tabel: Ervaringen van patiënten met informed consent:

\begin{tabular}{lc}
\hline Mijn huisarts gaf informatie over de behandeling & $91 \%$ \\
Mijn huisarts gaf informatie over behandelalternatieven & $49 \%$ \\
Mijn huisarts en ik beslissen samen & $60 \%$ \\
Uiteindelijk besliste mijn huisarts & $79 \%$ \\
Mijn cardioloog liet mij meebeslissen & $53 \%$ \\
Mijn gynaecoloog liet mij meebeslissen & $68 \%$ \\
Mijn orthopeed liet mij meebeslissen & $74 \%$
\end{tabular}

Samengesteld op basis van: R.D. Friele, A. Albada \& E.M. Sluijs, Patiënten over hun rechten in de gezondheidszorg, een overzichtsstudie ten behoeve van de SGZ 2006, Utrecht: SGZ 2006. 